\title{
Safety and Cross Protective Efficacy of Bacteriophage Lysate against Pasteurella multocida Infection in Mice
}

\author{
R. Durairajan*, Harshit Verma, Awadwsh Prajapati, \\ Mohammmed Abbas, Mayank Rawat and Rishender Verma
}

Division of Biological Standardization, Indian Veterinary Research Institute (IVRI),
Izatnagar, Dist. Bareilly, Uttar Pradesh, India

*Corresponding author

A B S T R A C T

Keywords

Bacteriophage, Lytic, P. multocida type A, Isolation, Therapeutic application

Article Info

Accepted:

07 September 2020

Available Online:

10 October 2020
In this study established the methodology to isolate highly virulent bacteriophage and assessed the ability of this phage lysate to induce protection against wild-type challenge in mice and the natural host chickens. Subcutaneous administration of phage lysate to mice stimulated significant protection against Pasteurella multocida $\mathrm{P}_{52}$ and $\mathrm{A} 1$ serotypes. But, significantly phage lysate was able to induce protection through subcutaneous route against challenge with wild type Pasteurella multocida A1 serotype in chicken but not through intranasal administration of phage lysates

\section{Introduction}

Haemorrhagic septicaemia (HS), the fatal septic-shock of cattle and buffaloes, and Fowl Cholera (FC) of poultry are the two 'Pasteurelloses' against which safe and effective bacterins are currently available commercially, and used.

Conventional inactivated bacterins against HS and FC lack the ability to induce an acrossserotype or serogroup response. HS vaccines containing killed whole cells of $\mathrm{P}_{52}$ (B: 2 ), or any of the recognized vaccine strain, along with an adjuvant, fail to induce a crossprotective response against serotypes of A (Samanta and Rawat 2005). Hence this study was made to determine bacteriophages, and phage lysate products have been identified as suitable alternative vaccine.

Also exploits cost protective solid immunity to control the different serotypes of Pasteurella multocida infection in poultry and livestock. 


\section{Materials and Methods}

\section{Bacteriophage isolation}

To isolate lytic bacteriophages, $1 \mathrm{ml}$ of $\log$ phase $P$. multocida culture in NZCYM broth (DIfco), $10 \mathrm{ml}$ NZCYM broth and $5 \mathrm{ml}$ farm yard slurry/pond water were combined and incubated at $37^{\circ} \mathrm{C}$ overnight in shaking incubator at $100 \mathrm{rpm}$. Next day, culture was centrifuged at $5000 \mathrm{rpm}$ to remove cell debris and clear supernatant was filtered $(0.22 \mu$ millipore) to obtain bacterial free filtrate (BFF). BFF was analyzed for the occurrence of lytic phage, if any, by soft agar overlay method (Adams, 1959)). In brief, four sterile test tubes each filled with $5 \mathrm{ml}$ soft NZCYM agar $(0.6 \%)$ were set in a water bath at $47^{\circ} \mathrm{C}$ to prevent agar from solidifying. First, second and third tubes were fed with one, three and six drops of BFF, whereas fourth tube was left unfed and served as control. Thereafter, each tube was added with $0.3 \mathrm{ml}$ early log phase pure culture. After a brief vortex, content of each tube was poured onto four separate petri plates each containing a layer of hardened bottom brain heart infusion agar (BHI) $2.5 \%$. The top soft agar was spread evenly on hard agar surface, allowed to stand at room temperature for $15 \mathrm{~min}$, incubated at $37^{\circ} \mathrm{C}$ for 18-24 hrs and inspected for Phage plaques. Phages were purified by streaking in individual plaque on BHI agar plates overlaid with NZCYM soft agar containing early log phase culture of respective indicator strains. Plates were incubated at $37^{\circ} \mathrm{C}$ for $18 \mathrm{~h}$ and inspected for clear zones around streak line. Phages were harvested with SM buffer (50 $\mathrm{mM}$ Tris-HCL (pH 7.5) $100 \mathrm{mM}$ Nacl, 10 $\mathrm{mM} \mathrm{MgSo}$, 2\% gelatin). Gross agar shreds were removed by slow speed centrifugation and supernatant containing purified phages were filtered through $(0.22 \mu)$. Purified phages were confirmed by plaque assay using the soft agar overlay method [Adams (1959)]. Briefly, 100 appropriately diluted phage and 300 early log phase culture of indicator organism were added to $5 \mathrm{ml}$ molten NZCYM soft agar (0.6\%), mix well poured on to BHI agar plates, incubated at $37^{\circ} \mathrm{C}$ for $18 \mathrm{~h}$ examined for plaques.

\section{Production and storage of homogenous phage stocks}

Bulk stocks of phages were prepared by conventional liquid culture methods described by Eisentark (1967) 1 litre of sterilized NZCYM broth in a flat bottom flask (3 litre capacity Hafkins flask) was separately inoculated with $50 \mu \mathrm{l}$ of 18 hour pure broth culture of $P$. multocida serotype A1 and incubated at $37^{0} \mathrm{C}$ for 2 hours. Stock suspension of phage was inoculated to attain 1:100 final phage bacterial ratio Rawat and Verma (2007). The phage bacteria mixtures were incubated at $37^{\circ} \mathrm{C}$ with vigorous intermittent shaking until complete lysis (approximately 6 hours was observed). The bacterial lysates were filtered through $0.22 \mu$ membrane filter and collected aseptically in sterile bottles. The stocks were stored at $4^{0} \mathrm{C}$ for 1 month to eliminate residual lytic activity attributed to phage induced enzymes. The sterility of phage stock was tested by standard methods (Indian Pharmacophoea, 1996). Using appropriate quantity soyabean casin digest medium and fluid thioglycolate medium.

\section{Determination of titration of phage of stock suspension}

Serial 100 fold dilution of phage stocks was prepared in sterile SM buffer. 100 $\mu$ l of each dilution beginning from $10^{2}$ onwards to $10^{12}$ was mixed with $300 \mu \mathrm{l}$ of 18 hour incubated pure NZCYM broth culture of P. multocida A1 in sterilized tubes. The phage bacteria mixture was allowed to stand at $37^{\circ} \mathrm{C}$ for 20 minutes. The content of each tube was then added to $3 \mathrm{ml}$ of sterile molten soft agar at 
$47^{\circ} \mathrm{C}$ mixed thoroughly by vortexing and immediately poured onto plates containing hardened $\mathrm{BHI}$ agar. The plates were incubated at $37^{\circ} \mathrm{C}$ for 18 hours and plaques were counted after incubation.

\section{Safety test}

Safety test of purified phage must conducted in mice. Four separate group of 5 mice each injected with phage $\left(10^{8} \mathrm{PFU} / \mathrm{mouse}\right)$ through $\mathrm{i} / \mathrm{m}, \mathrm{s} / \mathrm{c}, \mathrm{i} / \mathrm{p}$ and $\mathrm{i} / \mathrm{v}$ routes, were kept at constant monitoring under ideal condition for 20 days.

\section{In vivo prophylactic efficacy in mice}

Invivo prophylactic efficacy of phage against host bacterium (P. multocida serotype $\mathrm{P}_{52}$ and A1) was assessed in experimental mice. Healthy adult mice of either sex weighing not less than 18-20 grams where subdivided into 3 groups (G1-G3) of 3 mice each marked with positive control (G1) $1 \mu$ l of phage lysate $\left(10^{8}\right.$ PFU/ml) administered mice (G2) and $0.5 \mathrm{ml}$ of phage lysate administered mice is G3. After 4-5 hours administration of phage lysate all the groups (G1-G3) where s/c challenged with $0.2 \mathrm{ml}$ of experimentally grown $10^{6}$ dilution of $P$. multocida serotype $\mathrm{P}_{52}$ culture containing $5 \times 10^{8} \mathrm{CFU}$ following the lethal dose recommended by other investigation.

The safe experimental trial has been conducted against $P$. multocida serotype A1 as well. But the challenge dose of $P$. multocida A1 culture containing $5 \times 10^{9} \mathrm{CFU}$ ( $10^{7}$ dilution) were recommended.

In-vivo prophylactic efficacy in mice after 21 days administration of phage lysates and invivo prophylactic efficacy of phage lysate against host bacterium was assessed in experimental mice after 21 days administration of phage lysate. Healthy adult mice of either sex weighing not less than 18-
20 grams where subdivided into 3 groups (G1-G3) of 3 mice each marked with positive control (G1) $1 \mu$ l of phage lysate $\left(10^{8}\right.$ PFU/ml) administered mice (G2) and $0.5 \mathrm{ml}$ of phage lysate administered mice is G3. After $21^{\text {st }}$ day of administration of phage lysate all the groups were s/c challenged with $0.2 \mathrm{ml}$ experimentally grown 10 dilution containing $5 \times 10^{8}$ CFU P. multocida $\mathrm{P}_{52}$. The same experiments were conducted against the challenging organism of $P$. multocida A1. For challenging with A1 organism the recommended mouse lethal dose $10^{7}$ dilution containing $5 \times 10^{9} \mathrm{CFU} / \mathrm{ml}$. All the mice were observed for any mortality or morbidity until for $5^{\text {th }}$ days from the challege of the mice.

In-vivo prophylactic efficacy in birds challenged with Pasteurella multocida A1 serotypes

In-vivo prophylactic efficacy of phage lysate against host bacterium ( $P$. multocida A1 serotypes) was assessed apparently healthy birds (7-8 weeks) were subdivided into 3 groups G1 - G3 of 3 birds each. Marked G1 positive control, marked G2 phage lysates were administered through intra nasal and marked G3 phage lysate were administered through subcutaneous route. The dose rate of phage lysate is $100 \mu \mathrm{l}$ (1:2 dilution). All the birds were challenged with $1 \mathrm{ml}$ of $10^{7}$ dilution of experimentally grown $5 \times 10^{9}$ c.f.u/ml bacteria. Following the lethal dose recommended by other investigators, the birds were observed for any morbidity and mortality until $72 \mathrm{hr}$ after post challenge.

\section{Results and Discussion}

Lytic phages: Four lytic phages against the $P$. multocida A1 serotypes were isolated. Phages were christened as PM-IVRI-1, PM-IVRI-2 and PM-IVRI-3 respectively. But only one lytic phage against P.multocida $\mathrm{P}_{52}$ isolates were isolated. 
Safety test: All the groups of the mice which inoculated with phages were alive and active after 20 days of inoculation.

\section{In vivo prophylactic efficacy}

Mice were showing protection when it is challenged with $0.2 \mathrm{ml}$ of experimentally grown $10^{6}$ dilution of $P$. multocida $\mathrm{P}_{52}$ culture.

In vivo-prophylactic efficacy in mice after 21 days administration of phage lysates

Mice were inoculated with single dose of upto $10^{8}$ PFU phage lysates and 20 days apart the mice were challenged with highly virulent homologus as well as heterologus virulent bacteria. Both control mice were died after 24 hrs after challenge with lethal dose of A1 seotype. In contrast, mice immunized with phage lysate were showing $100 \%$ protected when immunized with the $1.0 \mu \mathrm{l}$ as well as 0.5 $\mu l$ of phage lysate.

In vivo prophylactic efficacy in natural host by challenging with P.multocida A1 serotype

Birds were injected with upto $10^{8}$ PFU phage lysates and $6 \mathrm{hrs}$ and 21 days apart the bird were challenged with highly virulent wild type $P$. multocida A1 serotype lethal dose.

In S/C inoculation one bird has survived after challenged with homologus strain of $P$. multocida. In contrast, intranasaly inoculated as well as control birds were being died after 24 hrs challenge.

Table:1 Protection acquired in mice by s/c immunization with phage lysates of P. multocida against P52

\begin{tabular}{|c|c|c|c|c|c|c|c|c|}
\hline Dose of phage & Challenge & No of mice & Sur & d mic & after & ialle & & \\
\hline lysate & dose P52 & Challenged & $24 h$ & $48 h$ & $72 \mathrm{~h}$ & $86 h$ & $120 h$ & 144h \\
\hline $1.0 \mu \mathrm{l}$ & $0.2 \mathrm{ml}$ & 3 & 2 & 1 & 1 & 1 & 1 & 1 \\
\hline $0.5 \mu l$ & $0-2 \mathrm{ml}$ & 3 & 3 & 3 & 2 & 1 & 1 & 1 \\
\hline Control & $0.2 \mathrm{ml}$ & 2 & Sick & diec & - & - & - & - \\
\hline
\end{tabular}

Table. 2 Protection acquired in mice by s/c immunization with phage lysates of P. multocida against A1 serotype

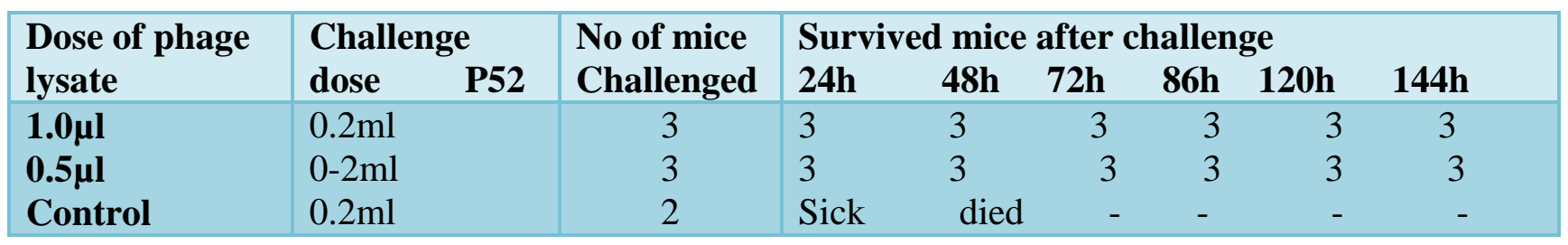

Table.3 Protection conferred in birds by s/c Immunization with phage lysates of $P$. multocida against wild $P$. multocida A1 serotype

\begin{tabular}{|c|c|c|c|c|c|c|c|}
\hline Group & $\begin{array}{l}\text { No of } \\
\text { birds }\end{array}$ & $\begin{array}{l}\text { Challenge of birds after } \\
\text { 6hr Post Innoculation }\end{array}$ & \multicolumn{5}{|c|}{$\begin{array}{l}\text { Survived birds after challenge } \\
24 \mathrm{hr} 48 \mathrm{hr} 72 \mathrm{hr} 96 \mathrm{hr} 120 \mathrm{hr} 144 \mathrm{hrs}\end{array}$} \\
\hline $\mathrm{S} / \mathrm{c}$ & 3 & $1.0 \mathrm{ml}\left(10^{-7}\right.$ Dilution $)$ & $3 \quad 1$ & 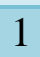 & 1 & 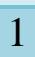 & 1 \\
\hline $\mathbf{I} / \mathbf{N}$ & 3 & $1.0 \mathrm{ml}\left(10^{-7}\right.$ Dilution $)$ & 2 & - & - & & - \\
\hline Control & 4 & $1.0 \mathrm{ml}\left(10^{-7}\right.$ Dilution $)$ & All Died & - & - & - & - \\
\hline
\end{tabular}


Table.4 Protection conferred in birds after 21 days immunization with phage lysates of $P$. multocida against wild P.multocida A1 serotype

\begin{tabular}{|c|c|c|c|c|c|c|c|}
\hline Group & No of birds & $\begin{array}{l}\text { Challege of birds after } \\
21 \text { day Post Inoculation }\end{array}$ & \multicolumn{5}{|c|}{$\begin{array}{c}\text { Survived birds after challenge } \\
24 \mathrm{hr} 48 \mathrm{hr} 72 \mathrm{hr} 96 \mathrm{hr} 120 \mathrm{hr} 144 \mathrm{hrs}\end{array}$} \\
\hline S/c & 2 & $1.0 \mathrm{ml}\left(10^{-7}\right.$ Dilution $)$ & 2 & 2 & 2 & 2 & 2 \\
\hline $\mathbf{I} / \mathbf{N}$ & 3 & $1.0 \mathrm{ml}\left(10^{-7}\right.$ Dilution $)$ & 2 & 1 & 1 & - & 1 \\
\hline Control & 4 & $1.0 \mathrm{ml}\left(10^{-7}\right.$ Dilution $)$ & All Died & - & - & - & - \\
\hline
\end{tabular}

Phage lysate were giving $100 \%$ protection when lysate were inoculated through $\mathrm{S} / \mathrm{C}$. In contrast, Intranasal inoculated birds were showing the $0 \%$ protection after 21 days immunization.

The high abundance of the $P$. multocida in livestock and poultry indicates its pathogenic importance. Minimizing its community spread and its economical loss has the primary task of modern medicine. In addition, inefficiency of most commonly used vaccines (Alum precipitated vaccine and Agar washed vaccines) advocate their ability to survive and keep them vicious cycle on in vaccine rich environment. Isolation of lytic phages against indicator P. multocida strain from farm yard slurry/pond illustrates the human/animals excreta is a rich repertoire of anti $P$. mltocida phages. Broad lytic efficacy of this phage to P.mltocida indicates it as safe antibacterial agent and thus therapeutic application of this phage would not hamber the growth of host normal microflora.

Phage lysates were recommended to safety suggest that inoculation of phage lysate at 10 fold higher doses $\left(10^{8}\right.$ p.f.u/ml $)$ to that of prophylactic dose $10^{7}$ was safe and thus phage lysate may be used for animal safety and followed by clinical prophylactic trials.

In-vivo protection efficacy of phage lysate in mice reveals its prophylactic significance to alleviate clinical symptoms induced by $P$. multocida challenge infection. Immunizing trial in mice involved phage lysed bacteria giving better protection as that live bacteria. Likewise, phage lysed salmonella have demonstrated to induce better protection than heat killed/formalin killed strain (Muotiala et $a l, 1989)$. The component of phage lysate are presented to the host in their natural antigenic state, which may altered by heat, formalin or other treatments used to kill bacteria. In addition, live antigenic states induced better cell mediated immunity than killed vaccines and live bacteria, but not killed bacteria, induce macrophage to produce high level of IL-12 in vivo, which can induced naive T-cell to produce IFN $¥$ (Th1 response), activating the bactericidal activity of macrophages and CD 8 cytotoxic $T$ cells, both component of cell mediated immunity (Matsui et al, 1992 and Cheers 1996). The identity and function of cross-protective antigen in P. multocida are still not well characterized, but several studies have indicated that cross protective factor are produced exclusively. In this study, phage lysate giving protection to the $P$. multocida infection in mice model as well as natural host. In this study, phage lysate were giving protection to the $P$. multocida infection in mice model as well as natural host. The importance of the phage lysed bacterial components has been giving protection/ resistance were suggested by various studies (Sulakvelidze et al., (2001), Pasterneck, 2009). However the role of phage lysate in acquired immunity has been controversial, but that is authenticated in the salmonella infection. Through the use of phage lysates, our results demonstrate for the first time that solid immunity to P. mltocida $\mathrm{B} 2$ and $\mathrm{A} 1$ can 
be stimulated by phage lysed bacterial components.

\section{References}

Adams, M, H. Bacteriphages. (1959). Interscience, New York.

Eisentark, A. Bacteriophage techniques In. (1967): Maramorsch K, Koprowski H (eds) Methods in Virology 1, Academic press, New York: 449.

Rawat and Verma, (2007). Isolation and characterization, preservation and therapeutic use of bacteriophage against Staphylococcus aureus associated with ruminant mastitis progress Department of biotechnology.

Muotiala A, Hovi M, Makela, P.H. (1989). Protective immunity in mouse salmonellosis: comparison of smooth and rough live and killed vaccines. Microbl Pathog. 6:51.
Matsui K, Arai T. (1992). The comparison of cell-mediated immunity induced by immunisation with porin, viable cells and killed cell of Salmonella typhimurium. Microbiol Immunol. 36(3): 269.

Cheers C, Zhan Y. (1996). How do macrophage distinguish the living from the dead? Trends Microbiology. 4(11): 453

Pasterneck, (2009). Method for vaccination of poultry by using Bacteriophage lysate bacterin. US 2009/0297561 A.

Sulakvelidze, A., Alavedize, Z. Morris G.Jr (2001). Bacteriophage Therapy. Antimicrobial Agents Chemother .45: 1045.

Samanta, I. And Rawat, M. (2005). Detection of immune response of lipopolysaccharide of Pasteurella multocida $\mathrm{B}: 2$ (P52) in rabbits by dotELISA. Indian J. Anim. Res., 39(2): 131.

\section{How to cite this article:}

Durairajan, R., Harshit Verma, Awadwsh Prajapati, Mohammmed Abbas, Mayank Rawat and Rishender Verma. 2020. Safety and Cross Protective Efficacy of Bacteriophage Lysate against Pasteurella multocida Infection in Mice. Int.J.Curr.Microbiol.App.Sci. 9(10): 732-737. doi: https://doi.org/10.20546/ijcmas.2020.910.088 